Joanna Sktadowska

Uniwersytet Jagielloński

\title{
POZYCJA USTROJOWA PREZYDENTA NIKARAGUI W KONTEKŚCIE NOWELIZACJI KONSTYTUCJI Z 10 LUTEGO 2014 R.
}

\section{Wstęp}

Początki konstytucjonalizmu nikaraguańskiego przypadają na schyłek ery kolonialnej i wiążą się z ruchami niepodległościowymi w regionie. W 1822 roku Nikaragua oswobodziła się spod zwierzchnictwa hiszpańskiego jako część cesarstwa Meksyku. Rok później weszła w skład Zjednoczonych Prowincji Ameryki Środkowej. W 1838 roku proklamowała niepodległość jako suwerenne państwo ${ }^{1}$. W tym okresie promulgowane zostały dwie pierwsze konstytucje: w 1824 roku Konstytucja Republiki Federacyjnej Ameryki Środkowej, w 1838 roku pierwsza Carta Magna niepodległej Nikaragui ${ }^{2}$.

Obecnie obowiązująca konstytucja ${ }^{3}$ jest dziesiątą ustawą zasadniczą Nikaragui. W chwili uchwalenia, stanowiła próbę implementacji zasad rewolucji sandinistowskiej na poziomie konstytucyjnym ${ }^{4}$. Blisko osiem lat, które upłynęły od przejęcia władzy, do wejścia w życie ustawy zasadniczej, świadczą o trudnościach sandinistów w połączeniu idei rewolucji z zasadami państwa demokratycznego ${ }^{5}$. Konstytucja okazała się aktem uniwersalnym, dając instytucjonalne ramy do rozpoczęcia procesu demokratyzacji oraz pokojowej transformacji państwa, po zwycięstwie opozycji w wyborach z 1990 roku $^{6}$.

1 T. Walker, C.J. Wade, Nicaragua, Living in the Shadow of the Eagle, Boulder 2011, s. 11.

2 A. Esguevera Gómez, Contexto histórico de las constituciones y sus reformas en Nicaragua, „Revista de Derecho" 2005, nr 10, s. 93-113.

3 Konstytucja Polityczna Republiki Nikaragui (Constitución Política de la República de Nicaragua) z dnia 19 listopada 1986 r. (Dz.U. La Gaceta 94 z 30.04.1987 r.).

4 Zastąpiła Statut Fundamentalny, przyjęty przez władze rewolucyjne dzień po obaleniu reżimu Anastazio Somozy -20 lipca $1979 \mathrm{r}$.

5 A. Aguilar Altamirano, A. Esperanza Silva, A. Sandino, M. Zepeda Rivera, Novena reforma constitucional 2014. El cambio de las reglas del juego democrático en Nicaragua, Managua 2014, s. 12.

6 S. Martí i Puig, Nicaragua y el FSLN (1979-2009): „Que queda de la Revolucion”, Barcelona 2009, s. 19-20. Więcej na temat: L.E. Anderson, L.C. Dodd, Learning Democracy. Citizen engagement and electoral choice in Nicaragua, 1990-2001, Chicago 2005, A. Gruszczak, Ameryka Środkowa, Warszawa. 2007, s. 452-460. 
Na przestrzeni blisko trzydziestu lat obowiązywania, konstytucja była kilkunastokrotnie nowelizowana. Oprócz legislatywy wpływ na jej kształt miała także władza sądownicza ${ }^{7}$. Na uwagę zasługują dwa wyroki Sądu Najwyższego: z dnia 19 października 2009 roku $^{8}$ oraz z dnia 30 września 2010 roku9. W pierwszy z nich sąd orzekł, że zakaz ponownej reelekcji, wprowadzony nowelizacją z 1995 roku, jest sprzeczny z nadrzędną zasadą woli suwerennego narodu. Prawo suwerena do oddania głosu na wybranego przez siebie kandydata nie może być ograniczone. Kolejne orzeczenie wyłączyło konstytucyjny zakaz ponownej reelekcji w odniesieniu do kandydatów, którzy sprawowali urząd prezydenta, wiceprezydenta oraz szefów i wiceszefów egzekutywy na szczeblu samorządowym. Choć literalnie brzmienie art. 147 i 178 konstytucji pozostało bez zmian, przywołane wyżej wyroki zniosły restrykcje co do liczny kadencji ${ }^{10}$.

\section{Tradycja systemu prezydenckiego}

W Nikaragui, podobnie jak w innych państwach Ameryki Łacińskiej, funkcjonuje system prezydencki. Uwzględniając kontekst kulturowy, źródeł takiego rozwiązania poszukiwać można jeszcze w czasach kolonialnych, kiedy poszczególne prowincje zarządzane były przez scentralizowany aparat wicekróla. Lokalnie władza ulegała dalszej personalizacji i wykonywana była przez niezależnych kacyków. Dominowała silna, autorytarna jednostka, skupiająca w swych rękach władzę wykonawczą, ustawodawczą, a niejednokrotnie także sądowniczą.

Ramy instytucjonalne latynoamerykańskiego systemu prezydenckiego tworzone były po uzyskaniu niepodległości, pozostając pod wyraźnym wpływem rozwiązań amerykańskich. Jego cechami charakterystycznymi są: legitymizacja władzy prezydenta gwarantowana bezpośrednimi wyborami, szeroki wachlarz kompetencji oraz brak wyraźnych mechanizmów kontroli ze strony władzy legislacyjnej. $Z$ uwagi na powyższe w literaturze zwykło się mówić o klasycznym systemie prezydenckim (w odniesieniu do Stanów Zjednoczonych) oraz prezydencjalizmie latynoamerykańskim ${ }^{11}$.

Takie rozwiązanie budzi spore zastrzeżenia, szczególnie, gdy uwzględni się okoliczność, iż funkcja sędziego Sądu Najwyższego jest kadencyjna, a wyboru dokonuje Zgromadzenie Narodowe. Inspirację zaczerpnięto z sąsiedniej Kostaryki, gdzie Sąd Najwyższy w wyroku z 14 kwietnia 2003 r. dopuścił do ponownego kandydowania na urząd prezydenta Oscara Ariasa, mimo iż konstytucja przewidywała bezwzględny zakaz reelekcji. Więcej na temat: E. Martínez Barahona, Brenes Barahona, „Y volver, volver, volver...” Una análisis de los casos de intervención de las Cortes Supremas en la Reelección Presidencial en Centroamérica, „Anuario de Estudios Centroamericanos" $2012 \mathrm{nr} 38$, s. 109-136.

$8 \quad$ Wyrok Izby Konstytucyjnej Sądu Najwyższego Nikaragui nr 504 z 19 października 2009 r.

$9 \quad$ Wyrok pełnego składu Sądu Najwyższego Nikaragui nr 6 z 30 września 2010 r.

10 Z dobrodziejstwa wyroku, w wyborach 2011 r. i 2012 r. skorzystał obecny prezydent Daniel Ortega oraz 109 przedstawicieli władzy na szczeblu lokalnym więcej na temat: E. Martínez Barahona Elena, A. Brenes Barahona, Y volver, volver..., op. cit., s. 118-123.

11 M. Serrafero, Presidencialismo y parlamentarismo en América Latina: un debate abierto, „Revista Mexicana de Sociología" 1998, $60 \mathrm{nr}$ 2, s. 171. 
Pozycja ustrojowa Prezydenta Nikaragui, w kontekście nowelizacji Konstytucji...

\section{Ramy ustrojowe}

Zgodnie z art. 7 konstytucji, Nikaragua jest republiką demokratyczną. Wola narodu - suwerena realizowana jest za pośrednictwem czterech władz: ustawodawczej, wykonawczej, sądowniczej i wyborczej. Ustawa zasadnicza szczegółowo określa kompetencje każdej z nich, nakładając zarazem obowiązek wzajemnej współpracy. Legislatywa należy do jednoizbowego Zgromadzenia Narodowego (Asemblea Nacional), złożonego z dziewięćdziesięciu deputowanych, wybieranych w wyborach powszechnych, równych, bezpośrednich, wolnych, w głosowaniu tajnym, przy zastosowaniu systemu proporcjonalnego (art. 132 do 143). Władza wykonawcza spoczywa w rękach Prezydenta (Presidente), który jest zarazem głową państwa, szefem rządu oraz naczelnym zwierzchnikiem nikaraguańskich sił zbrojnych (art. 144 do 153). Władzę sądowniczą wykonują sądy i trybunały o zhierarchizowanej strukturze, na czele której stoi Sąd Najwyższy (Corte Suprema de Justicia) (art. 158 do 167). Głównym organem władzy wyborczej jest Najwyższa Rada Wyborcza (Consejo Supremo Electoral). Do jej wyłącznej kompetencji należy organizacja, przeprowadzenie i kontrola nad przebiegiem wyborów, plebiscytów oraz referendów (art. 168 do 174).

\section{Pozycja ustrojowa prezydenta Nikaragui}

W Nikaragui przyjęto monokratyczną strukturę egzekutywy. Zgodnie z art. 144 konstytucji, prezydent jest jedynym podmiotem uprawnionym do sprawowania władzy wykonawczej. W sprawowaniu władzy wspiera go wiceprezydent oraz rada ministrów - podmioty tworzące aparat administracyjny egzekutywy.

\subsection{Procedura wyborcza}

Zgodnie z treścią art. 146, in principio, wybory prezydenckie są wyborami pięcioprzymiotnikowymi, tj.: powszechnymi, równymi, bezpośrednimi, wolnymi, odbywającymi się w głosowaniu tajnym. W oryginalnym brzmieniu cytowanego artykułu, głowa państwa wybierana miała być zwykłą większością głosów. Nowelizacja konstytucji z 1995 roku wprowadziła zasadniczą zmianę ${ }^{12}$. W sytuacji gdy żaden z kandydatów nie uzyskałby określonej większości (czterdzieści pięć procent ważnie oddanych głosów), konieczna stawała się druga tura wyborów, do której przechodziliby kandydaci z dwoma najlepszymi wynikami. Dogrywka rozstrzygana miała być zwykłą większością. Dalsze zmiany przyniosła nowelizacja konstytucji z 2000 roku, która obniżyła próg warunkujący konieczność przeprowadzenia drugiej tury. Ustawodawca przewidział dwa warianty. Już w pierwszej turze zwycięzcą wyborów prezydenckich zostać mógł kandydat, który uzyskał: albo nie mniej niż czter-

12 Więcej na temat: M. Gerpe Landín, J. Vintró Castells, Aproximación a la reforma constitucional de Nicaragua, „Revista de Sociologia” 1996 nr 49, s. 105-118. 
dzieści procent ważnie oddanych głosów, albo nie mniej niż trzydzieści pięć procent ważnie oddanych głosów, natomiast wynik kolejnego kandydata był gorszy od zwycięzcy o więcej niż pięć punktów procentowych ${ }^{13}$. Kolejne zmiany wprowadziła nowela z lutego 2014 roku, o czym niżej.

\subsection{Reelekcja}

Większość konstytucji państw demokratycznych ogranicza liczbę kadencji prezydenckich. Rozwiązaniem skrajnym jest zakaz reelekcji o charakterze absolutnym (jak np. w Meksyku, czy Gwatemali). W wariantach pośrednich, ponowny wybór jest dopuszczalny po spełnieniu określonych warunków. Restrykcje dotyczą najczęściej liczby lub bezpośredniości reelekcji. Akceptowana może być: (i) jednokrotna reelekcja bezpośrednia i otwarta (gdzie po dwóch kadencjach były prezydent może startować w kolejnych wyborach, jednak po odczekaniu określonego czasu), (ii) jednokrotna reelekcja bezpośrednia i zamknięta (gdzie po dwóch, następujących po sobie kadencjach były prezydent traci prawo do startowania w wyborach), (iii) reelekcja niebezpośrednia i otwarta (w której ponowne kandydowanie po upływającej kadencji nie jest możliwe, jednak po odczekaniu określonego czasu były prezydent, bez ograniczeń starać się może o urząd), (iv) niebezpośrednia reelekcja zamknięta (w której, po upływie okresu karencji, były prezydent może starać się o urząd ponownie, lecz tylko określoną liczbę razy) ${ }^{14}$. Uwzględniając kontekst historyczny, za stosowaniem zakazu reelekcji przemawia założenie, że limit czasowy sprawowania władzy stanowić będzie skuteczną zaporę dla nawrotu dyktatur ${ }^{15}$.

W oryginalnym brzmieniu, nikaraguańska konstytucja nie wprowadzała ograniczeń w liczbie kadencji prezydenckich. Jej twórcy wskazywali, że formalny zakaz reelekcji nie uchronił Nikaragui przed przeszłoczterdziestoletnią dyktaturą klanu Somozów ${ }^{16}$. Obostrzenia w tym zakresie inkorporowała nowela z roku 1995. Po pierwsze, wyłączono reelekcję bezpośrednią. Po drugie, o ponowny wybór nie mogła się starać osoba, która sprawowała urząd prezydenta dwukrotnie. Warunki te zniosła nowelizacja z 2014 roku.

\footnotetext{
13 Zasady te znalazły zastosowanie po raz pierwszy w wyborach prezydenckich z listopada $2006 \mathrm{r}$. W konsekwencji, prezydentem wybrany został José Daniel Ortega Saavedra, który uzyskał niecałe trzydzieści osiem procent głosów.

Więcej na temat: M. Serrafero, El control de la sucesión: reelección y limitaciones de elección presidencial por parentesco en América Latina, „Revista de estudos e pesquisas sobre as Américas” 2015, 9 nr 1, s. 81-103, I. Tremino Sánchez, Las reformas a la reelección presidencial en América Latina, „Estudios Sociológicos” 2013, $31 \mathrm{nr}$ 91, s 59-85.

15 Źródeł zakazu ponownego wyboru na urząd prezydenta w Ameryce Łacińskiej szukać należy w jednym z kluczowych haseł („no reelección”) rewolucji meksykańskiej z 1910 r. Formalny zakaz reelekcji nie uchronił jednak wielu państw latynoamerykańskich przed dyktaturami. Obecnie w regionie zauważalna jest fala „reelekcjonizmu” - wprowadzania zmian konstytucyjnych w zakresie zniesienia lub ograniczenia zakazu reelekcji.

16 E. Castro Rivera, S.J. Cuarezma Terían, A 21 años de la Constitución Política: vigencia y desafíos, Managua 2008, s. 209.
} 


\subsection{Wymogi dla kandydata na prezydenta}

Wymogi stawiane kandydatom na prezydenta Nikaragui określone zostały w art. 147 konstytucji. Przepis ten przewiduje konieczność spełnienia czterech przesłanek pozytywnych, tj.: ukończenie odpowiedniego wieku (dwadzieścia pięć lat), dysponowanie pełnią praw cywilnych i politycznych, posiadanie wyłącznie obywatelstwa nikaraguańskiego (od zrzeczenia się obywatelstwa innego państwa winny upłynąć nie mniej niż cztery lata), stałe zamieszkiwanie na terenie Nikaragui od co najmniej czterech lat przed wyborami (z wyjątkiem osób odbywających służbę dyplomatyczną w placówkach zagranicznych, studiujących poza krajem pochodzenia lub pracujących w organizacjach międzynarodowych). Przywołany przepis określa także przesłanki negatywne. W wyborach nie może startować osoba, która: jest krewnym (do czwartego stopnia pokrewieństwa) lub powinowatym (do drugiego stopnia powinowactwa) byłego lub ustępującego prezydenta, przeprowadziła lub sfinansowała zamach stanu, jest księdzem lub duchownym innego wyznania, lub w okresie krótszym niż rok przed startem w wyborach pełniła funkcje w kluczowych organach i instytucjach państwowych.

\subsection{Kompetencje prezydenta}

Art. 150 konstytucji zawiera katalog podstawowych kompetencji prezydenta Nikaragui. Nie jest to katalog zamknięty, a dalsze uprawnienia wynikać mogą z kolejnych postanowień konstytucji oraz ustaw szczegółowych.

Kompetencje głowy państwa uporządkować można w kilka grup. Prezydent:

1) to strażnik porządku prawnego: ma gwarantować przestrzeganie prawa (w tym konstytucji), poszanowanie dla władzy sądowniczej, wykonalność wyroków sądowych,

2) to reprezentant narodu, a jego szeroki mandat legitymizuje wola suwerena, wyrażona w wyborach powszechnych, bezpośrednich i demokratycznych,

3) to czynny uczestnik procesu legislacyjnego. Posiada inicjatywę ustawodawczą, a także prawo weta. Zgodnie $\mathrm{z}$ art. 142 konstytucji, w terminie czternastu dni od uchwalenia ustawy prezydent może zawetować cały akt (weto całościowe) lub poszczególne jego artykuły (weto częściowe). W tym drugim przypadku, jest uprawniony do wprowadzania poprawek. Prezydenckie weto może zostać odrzucone przez deputowanych (w przypadku weta całościowego, głosami ponad połowy ustawowego składu Zgromadzenia, a przy wecie częściowym - głosami ponad połowy deputowanych biorących udział w głosowaniu),

4) jest odpowiedzialny za kształtowanie i prowadzenie polityki zagranicznej państwa. Posiada kompetencje do negocjowania i podpisywania umów oraz konwencji międzynarodowych, wnosząc następnie o ich ratyfikację przez parlament. 
5) to szef administracji państwowej zarządzający państwem. Organizuje i przewodniczy pracom rządu. Mianuje najwyższych urzędników państwowych, w tym: ministrów i wiceministrów, prokuratora generalnego i jego zastępców, dyrektorów jednostek autonomicznych, szefów jednostek dyplomatycznych. Ma faktyczny wpływ na wybór m.in. członków Sądu Najwyższego, Najwyższej Rady Wyborczej, Najwyższej Izby Kontroli etc. Do jego kompetencji należy przedstawianie parlamentowi list kandydatów na wymienione stanowiska, spośród których dokonywany jest wybór,

6) w stanach wyjątkowych jest uprawniony do wydania dekretu, stanowiącego podstawę prawną do podjęcia środków nadzwyczajnych. Mogą one m.in. prowadzić do ograniczenia lub zawieszenia praw i gwarancji obywatelskich (jednak na czas nie dłuższy niż siedemdziesiąt dwie godziny, pod warunkiem jednoczesnego skierowania wydanego dekretu do zatwierdzenia przez parlament),

7) to naczelny wódz wojsk,

8) prowadzi politykę ekonomiczną kraju i określa program ekonomiczno-społeczny. Do jego obowiązków należy również opracowanie projekt budżetu.

9) pełni funkcje honorowe: przyznaje nagrody i ordery o charakterze narodowym.

\section{Nowelizacja Konstytucji Nikaragui z 10 lutego 2014 roku}

Po przejściu dwukrotnej ścieżki legislacyjnej, odpowiednio w grudniu 2013 roku i styczniu 2014 roku (wymóg proceduralny), w dniu 10 lutego 2014 roku weszła w życie ustawa nr 854 o częściowej reformie Konstytucji Politycznej Republiki Nikaragui. Nowela dokonała zmiany pięćdziesięciu ośmiu artykułów ustawy zasadniczej. Jak przeczytać można w uzasadnieniu projektu zmian, reformę motywowały cztery kluczowe kwestie: potrzeba uwzględnienia w konstytucji nowych granic państwa na Morzu Karaibskim (na skutek wyroku Międzynarodowego Trybunału w Hadze); konieczność podkreślenia roli jednostki, rodziny i wspólnoty; instytucjonalizacja demokracji bezpośredniej inspirowanej walorami chrześcijańskimi, ideami socjalistycznymi i solidarnością oraz wzmocnienie systemu sądowniczego ${ }^{17}$. Nie odniesiono się zaś do zmian dotyczących władzy wykonawczej, mimo że de facto mają one fundamentalne znaczenie.

Komentowana nowelizacja zniosła formalne obostrzenia dotyczące wyboru prezydenta. Wykreślony został zakaz reelekcji, tym sankcjonując wcześniejsze wyroki Sądu Najwyższego. Zrezygnowano z dwóch tur wyborczych oraz wymogu uzyskania kwalifikowanej większości. Obecnie prezydent Nikaragui wybierany będzie zwykłą większością głosów. 
Głowa państwa zyskała nowe uprawnienia. Zgodnie z aktualnym brzmieniem art. 150 pkt 4) ustawy zasadniczej, prezydent władny jest do wydawania dekretów wykonawczych o charakterze abstrakcyjnym, w zakresie administracji. Ustawodawca zapomniał o definicji legalnej tego pojęcia, nie wskazując też przykładowego katalogu owych aktów. Stwarza to pole do nadużyć szczególnie, że nie zastrzeżono ograniczeń czasowych, czy też obowiązku ich następczego zatwierdzenia przez inny organ. Istnieje ryzyko, że korzystając z nowego uprawnienia prezydent będzie wydawał dekrety o znacznie szerszym zastosowaniu, ingerując tym samym w kompetencje władzy ustawodawczej.

Nowelizacja z 2014 roku wzmocniła także pozycję prezydenta jako naczelnego zwierzchnika sił zbrojnych. Uprzednio relacja na linii władza wykonawcza - armia przebiegała przy pośrednictwie Ministerstwa Obrony. Obecne brzmienie art. 95 konstytucji wskazuje, iż wojsko podporządkowane jest władzy cywilnej, sprawowanej bezpośrednio przez prezydenta. To samo dotyczy policji państwowej. Po nowelizacji art. 97 konstytucji policja podlega bezpośrednio prezydentowi, z wykluczeniem konieczności pośrednictwa Ministerstwa Spraw Wewnętrznych.

\section{Podsumowanie}

System prezydencki obwiązujący w Nikaragui gwarantuje prezydentowi szeroki wachlarz kompetencji. Jest on jedynym organem egzekutywy sprawującym rządy w państwie. W celu wykonywania swoich obowiązków, ma do dyspozycji odpowiedni aparat administracyjny, który tworzą m.in. wiceprezydent, ministrowie, czy wiceministrowie. Prezydent prowadzi politykę zagraniczną, reprezentuje naród, a także jest szefem sił zbrojnych oraz policji narodowej.

Nowelizacja konstytucji z lutego 2014 roku dokonała dalszego wzmocnienia pozycji głowy państwa. Uproszczona została procedura wyborcza oraz relacje z wojskiem i policją. Zniosiono zakaz reelekcji. Uwzględniając uwarunkowania historyczne oraz stan demokracji w Nikaragui, wprowadzone zmiany budzą poważne wątpliwości. Skupienie uprawnień w rękach jednostki, która sprawować może władzę bez ograniczeń czasowych, przy braku transparentności w wyborach, może usankcjonować nową dyktaturę. Osłabienie systemu kontroli, eliminacja instytucji pośrednich pomiędzy prezydentem a wojskiem i policją, może sprawić, że w sprzyjających okolicznościach prezydent nie zawaha się ich użyć do obrony własnych interesów.

W dojrzałej demokracji, gdzie zagwarantowane są prawa jednostek, a proces wyborczy przebiega bez zarzutów, wprowadzone nowelą z lutego 2014 r. zmiany nie budziłyby większego sprzeciwu. Realia nikaraguańskie i rosnąca pozycja Daniela Ortegi sprawiają, że pytanie o stan demokracji w tym małym środkowoamerykańskim kraju zyskuje aktualność. 


\section{BIBLIOGRAFIA}

Aguilar Altamirano Alejandro, Ada Esperanza Silva, Adelmo Sandino, Mireya Zepeda Rivera. 2014. Novena reforma constitucional 2014. El cambio de las reglas del juego democrático en Nicaragua. Managua: Instituto de Estudios Estratégicos y Políticas Públicas.

Anderson Leslie E., Lawrence C. Dodd. 2005. Learning Democracy. Citizen engagement and electoral choice in Nicaragua, 1990-2001. Chicago: The University of Chicago Press.

Castro Rivera Edwin, Sergio J. Cuarezma Terían. 2008. A 21 años de la Constitución Política: vigencia y desafíos. Managua: Instituto de Estudio e Investigación Jurídica.

Esguevera Gómez Antonio. 2005. „Contexto histórico de las constituciones y sus reformas en Nicaragua. Instituto de Historia de Nicaragua y Centroamérica”. Revista de Derecho 10: 93-113.

Gerpe Landín Manuel, Joan Vintró Castells. 1996. „Aproximación a la reforma constitucional de Nicaragua". Papers. Revista de Sociologia 49: 105-118.

Gruszczak Artur. 2007. Ameryka Środkowa. Warszawa: Wydawnictwo TRIO.

Martí i Puig Salvador. 2009. Nicaragua y el FSLN (1979-2009): ¿Que queda de la Revolucion? Barcelona: Edicions Bellaterra.

Martínez Barahona Elena, Amelia Brenes Barahona. 2012. „„,Y volver, volver, volver...” Una análisis de los casos de intervención de las Cortes Supremas en la Reelección Presidencial en Centroamérica". Anuario de Estudios Centroamericanos. Universidad de Costa Rica 38: 109-136.

Serrafero Mario. 1998. „Presidencialismo y parlamentarismo en América Latina: un debate abierto.” Revista Mexicana de Sociología 60 (2): 165-186.

Serrafero Mario 2015. „El control de la sucesión: reelección y limitaciones de elección presidencial por parentesco en América Latina". Revista de estudos e pesquisas sobre as Américas 9 (1): 81-103.

Tremino Sánchez Ilka. 2013. „Las reformas a la reelección presidencial en América Latina”. Estudios Sociológicos, 31 (91): 59-85.

Walker Thomas, Christine J. Wade. 2011. Nicaragua. Living in the Shadow of the Eagle. Boulder: Westview Press 


\section{THE POSITION OF THE PRESIDENT IN THE POLITICAL SYSTEM OF NICARA- GUA IN THE CONTEXT OF THE CONSTITUTIONAL REVISION OF FEBRUARY, 10TH OF 2014}

The latter Reform of the Political Constitution of the Republic of Nicaragua, entered into force in February 2014. The law has strengthened the political position of the president. He gained new competences and presidential term limits set by the constitution were overturned, thus creating the possibility to hold the office indefinitely.

The purpose of the article is to present the political position of the president of Nicaragua. and includes the changes introduced by the latter reform. The author assesses the reform and in particular removal of the reelection ban which may be viewed as a threat to democracy.

Keywords: president of Nicaragua, constitution of Nicaragua, executive power, reform of the Nicaraguan constitution, Daniel Ortega

Słowa kluczowe: Prezydent Nikaragui, Konstytucja Nikaragui, władza wykonawcza, nowelizacja konstytucji Nikaragui, Daniel Ortega 